\title{
Production of Chemically and Microwave Activated Hazelnut Husk As An Adsorbent for Dye Contaminated Wastewaters
}

\author{
Nilufer Ulgudur ${ }^{1}$ (D), Pinar Sevim Elibol ${ }^{1 *}(\mathbb{D})$, Emine Malkoc ${ }^{1}$ \\ ${ }^{1 *}$ Department of Environmental Engineering, Duzce University, Duzce, Turkey
}

\begin{abstract}
Cite this paper as:
Ulgudur, N., Sevim Elibol, P., Malkoc,E. (2022). Production of Chemically and Microwave Activated Hazelnut Husk As An Adsorbent for Dye Contaminated Wastewaters. Journal of Innovative Science and Engineering. 6(1): 46-60

*Corresponding author: Pinar Sevim Elibol E-mail: pinarsevim@duzce.edu.tr
\end{abstract}

Received Date: 29/03/2021

Accepted Date: 18/09/2021

(C) Copyright 2022 by

Bursa Technical University. Available online at http://jise.btu.edu.tr/

\section{(i) (8)}

The works published in Journal of Innovative Science and Engineering (JISE) are licensed under a Creative Commons Attribution-NonCommercial 4.0 International License.

\begin{abstract}
Adsorption has traditionally been evaluated as an economical and easily applicable process for treating certain wastewaters, such as ones including dyes and heavy metals. Even though adsorbent materials specifically produced for the purpose of wastewater treatment commercially exist, the production cost may create an economic burden on wastewater treatment processes. Agricultural wastes can be valorized as adsorbents in adsorption processes. The adsorption capacity of these wastes can be improved via pre-treatment methods such as chemical application and microwave irradiation. This study investigated the potential applicability of hazelnut husk as an adsorbent for methylene blue (MB) dye. To this purpose, the husk was activated by sequential chemical or water and microwave applications. Structural analysis on the produced adsorbent was performed by Fourier transform infrared spectrophotometry (FTIR) and field emission scanning electron microscopy (FE-SEM). Isotherm (Langmuir, Freundlich, Temkin and Harkins-Jura isotherms) and kinetic (pseudofirst-order, pseudo-second-order, Elovich and intraparticle diffusion kinetic models) behaviours of adsorption were also evaluated. The results indicated that MB could be removed by $92-94 \%$ considering all adsorbents produced. Further isotherm and kinetic studies revealed that $\mathrm{MB}$ adsorption was both physically and chemically induced, and the reaction followed the pseudo-second-order kinetic model $\left(\mathrm{R}^{2}>0.99\right)$.
\end{abstract}

Keywords: Adsorption, Dye, Waste, Microwave, Hazelnut Husk, Adsorbent 


\section{Introduction}

The adsorption process can be defined as the concentration or deposition of solute molecules on a porous solid material, i.e. adsorbent, via intermolecular attraction forces [1]. Adsorption processes can be employed in the removal of contaminants, including dyes, phenols, other organic pollutants such as pharmaceuticals, surfactants, solvents etc. [1] and heavy metals [2]. Adsorption has been considered as a viable option for wastewater treatment processes due to its simplicity in operation, feasibility, cost-effectiveness and insensitivity for toxic compounds [3-5]. Adsorption can be preferable over biological, chemical or physical methods like membrane processes, flocculation/coagulation, advanced oxidation, extraction, biodegradation as a treatment process depending on these benefits offered [6].

Dye containing wastewater (DCWW) can be considered one of the most crucial wastewater streams to employ adsorption treatment based on the pollution potential of dyes. DCWW can originate from many industries such as textile, paper, pharmaceutical, chemical, food, tannery. The annual production of dyes has been estimated as 700,000 tons [5], which results in large volumes of DCWW generation. Legislations are regulating their discharge into water bodies. DCWW requires treatment before discharge since mutagenic and carcinogenic effects can be observed on aquatic organisms [3]. However, DCWW can also be illegally discharged from the industries, potentially contaminating water bodies [6]. Dye contamination at concentrations of $1 \mathrm{ppm}$ or even lower can be detectable by the naked eye [3].

Moreover, more than $45 \%$ of organic pollution is grounded on the use of dyes [6]. Among the dyes used in industries, methylene blue (MB) is a cationic thiazine one [6] and it has a high solubility in water [5]. It is frequently used in cotton, wool and silk dying processes and as a biological staining agent $[3,5]$. Paper, pulp, textile, food, plastics, mills and leather are the related industries with MB use [6]. Cationic dyes present more toxicity compared to anionic and nonionic ones [6]. Methemoglobinemia, burning sensation, mental confusion, vomiting, nausea and profuse sweating are adverse health effects that can be experienced by MB exposure [3].

Treatment of DCWW can be problematic since they may contain refractory compounds that may resist the treatment involving digestion, light, heat and oxidizing agents [3]. Therefore, adsorption has been recognized as a viable process for the treatment of such wastewater streams. Activated carbon (AC) presents a viable option considering its effective dye treatment performance. However, the high cost of $\mathrm{AC}$ is the main limitation that hinders its wide range of applicability in wastewater treatment. Carbonaceous, metallic and magnetic nanomaterials, biosorbents such as chitosan and its composites and the composites of $\beta$-cyclodextrin and geopolymers have also been investigated for wastewater treatment [7]. Recent studies focus on developing economically viable and environmentally friendly adsorbents for wastewater treatment purposes. Employing agricultural, household, and industrial by-products in wastewater treatment can be considered a sustainable approach. This approach contributes to waste minimization and/or its recovery or reuse while treating wastewaters [8].

Agricultural wastes have the potential to be economical and environmentally friendly adsorbents depending on their chemical composition, abundance, renewability and cheap value $[3,9]$. The production of agricultural wastes is directly related to the crops of regional cultivation. Hazelnut production in Turkey has been estimated to be approximately $70 \%$ of global production [10]. Annual husk waste produced is $180-200,000$ tons in Turkey, corresponding to the hazelnut 
production of 500-600,000 tons/year [11]. The husk is a waste with no intended use and it has no economic value [12]. The use of husk in adsorption processes can potentially provide an economic value to husk waste and reuse.

Agricultural wastes can be applied without pretreatment or after pretreatment in adsorption processes. Pretreatment is generally applied to modify and improve the number of active sites so that the adsorption capacity is increased [8]. Pretreatment options include various physical and/or chemical activation methods. Thermal pre-treatment, applications of acidic (e.g. $\mathrm{H}_{2} \mathrm{SO}_{4}, \mathrm{H}_{3} \mathrm{PO}_{4}$ ) or basic solutions (e.g. $\mathrm{NaOH}, \mathrm{NaHCO}_{3}$ ) or particulates (e.g. $\mathrm{ZnCl}_{2}$ ) can be accounted as pretreatments methods [9]. Recent studies have focused on the emerging technology of microwave irradiation as a pretreatment option. Microwave irradiation prevents the formation of thermal gradients in solid materials while heating. Thermal gradient entraps volatile compounds and pyrolysis gasses which may clog the active sites for adsorption. Thus, microwave application can improve the functional groups on the adsorbent material and increase the carbon to oxygen ratio, which can also improve adsorption capacities [13]. Hazelnut husk has been previously treated with several chemicals $\left(\mathrm{H}_{3} \mathrm{PO}_{4}, \mathrm{KCH}_{3} \mathrm{COO}\right)$ and heat under nitrogen flow to produce activated carbon for the removal of $\mathrm{MB}$ [12], cadmium (II) [14] and copper (II) [15]. Activated carbon produced from hazelnut husk was also modified with zinc chloride $\left(\mathrm{ZnCl}_{2}\right)$ to produce an adsorbent for $\mathrm{MB}$ removal [16]. Hazelnut husk was sequentially treated by $\mathrm{H}_{2} \mathrm{SO}_{4}$ and $\mathrm{NaHCO}_{3}$ solutions for nickel (II) adsorption [17]. However, hazelnut husk has not been previously subjected to consecutive chemical and microwave treatments for adsorbent production, with the aim of dye removal. The dye adsorption capacity of microwave-assisted chemically activated hazelnut husk is yet to be revealed.

This study investigated the MB removal potential of husk waste after consecutive chemical or water and microwave pretreatments to valorize agricultural waste without any economic value. To this purpose, husk was first subjected to pretreatment using deionized water, sodium carbonate $\left(\mathrm{Na}_{2} \mathrm{CO}_{3}\right)$ and potassium carbonate $\left(\mathrm{K}_{2} \mathrm{CO}_{3}\right)$ and irradiated in a microwave oven. The results were promising in terms of providing an economic value to the waste as well as functionality.

\section{Material and Methods}

\subsection{Preparation of Adsorbents}

Husk was washed with tap water and dried in an oven for a day. It was grounded to obtain husk particles in the size range of 0.5-2 mm. Three setups were prepared. Deionized water, $\mathrm{Na}_{2} \mathrm{CO}_{3}(4 \mathrm{M})$ and $\mathrm{K}_{2} \mathrm{CO}_{3}(4 \mathrm{M})$ as activators were added to the husk particles to obtain a slurry in setups 1,2 and 3, respectively. The slurry was stirred for a day at room temperature on an orbital shaker. Deionized water and chemically $\left(\mathrm{Na}_{2} \mathrm{CO}_{3}, \mathrm{~K}_{2} \mathrm{CO}_{3}\right)$ treated slurry were subjected to irradiation under a laboratory microwave oven at $500 \mathrm{~W}, 60{ }^{\circ} \mathrm{C}$ for 7 minutes. The slurry was filtered through a coarse filter. It was rinsed with distilled water and dried at $100{ }^{\circ} \mathrm{C}$ for $24 \mathrm{~h}$. It was further employed in the adsorption process for MB removal. The related experimental conditions and the corresponding nomenclatures for the adsorbents are given in Table 1. 
Table 1. Experimental conditions for adsorbents produced

\begin{tabular}{llll}
\hline $\begin{array}{l}\text { Activator } / \\
\text { Nomenclature }\end{array}$ & $\begin{array}{l}\text { Volume of } \\
\text { activator }(\mathbf{m L})\end{array}$ & $\begin{array}{l}\text { Amount of } \\
\text { husk }(\mathbf{g})\end{array}$ & $\begin{array}{l}\text { Microwave operating } \\
\text { conditions }\end{array}$ \\
\hline Deionized water $(\mathbf{H W})$ & 70 & 10 & $500 \mathrm{~W}, 60{ }^{\circ} \mathrm{C}, 7 \mathrm{~min}$ \\
$\mathbf{N a}_{2} \mathbf{C O}_{3}(\mathbf{H N a})$ & 60 & 10 & $500 \mathrm{~W}, 60^{\circ} \mathrm{C}, 7 \mathrm{~min}$ \\
$\mathbf{K}_{2} \mathbf{C O}_{3}(\mathbf{H K})$ & 60 & 10 & $50060^{\circ} \mathrm{C}, 7 \mathrm{~min}$ \\
\hline
\end{tabular}

\subsection{Structural Analysis}

The structures of husk and adsorbents were analyzed by Fourier transform infrared spectrophotometry (FTIR) and field emission scanning electron microscopy (FE-SEM). The functional groups on both husk and adsorbents were determined by FTIR analysis (Shimadzu IRPrestige 21). FTIR resolution was $1 \mathrm{~cm}^{-1}$ and the data were acquired for the wavelength interval between 40 and $4000 \mathrm{~cm}^{-1}$. FE-SEM images were obtained using Quanta FEG 250 instruments (FEI Co., Hillsboro, OR, USA).

\subsection{Adsorption Experiment}

A stock MB solution of $500 \mathrm{mg} / \mathrm{L}$ concentration was prepared and diluted by $1 / 10$ for the adsorption experiment. Adsorption experiment was conducted with $200 \mathrm{~mL}$ of $50 \mathrm{mg} / \mathrm{L} \mathrm{MB}$ solution and $1 \mathrm{~g} / \mathrm{L}$ adsorbent dosage. The $\mathrm{pH}$ of the MB solution was approximately 5.5 and the experiment was carried out at room temperature under constant stirring at $190 \mathrm{rpm}$ on an orbital shaker. The total operation time was $1080 \mathrm{~min}$ and samples were withdrawn at times 10, 30, 60, 120, 240, 300, 360, 1020 and $1080 \mathrm{~min}$. MB concentration was measured by a UV-Vis spectrophotometer under $663 \mathrm{~nm}$ wavelength.

\subsection{Isotherm And Kinetic Analysis}

Isotherm and kinetic analysis were performed on adsorption data. Four isotherm models were studied (Langmuir, Freundlich, Temkin and Harkins-Jura isotherms). Kinetic behaviours were analysed by pseudo-first-order, pseudosecond-order, Elovich and intraparticle diffusion models.

\section{Results and Discussion}

\subsection{Structural Analysis Of Adsorbents}

FTIR analyses were conducted to determine the surface functional groups of husk and adsorbents produced (Figure 1). The bands located at $3334 \mathrm{~cm}^{-1}$ and $1610 \mathrm{~cm}^{-1}$ can be attributed to $\mathrm{O}-\mathrm{H}$ stretching vibrations originating from phenols, alcohols or adsorbed water molecules [18]. The bands at $2922 \mathrm{~cm}^{-1}$ and $2851 \mathrm{~cm}^{-1}$ can be ascribed to asymmetric C-H stretching and symmetric $\mathrm{C}-\mathrm{H}$ bending absorption bands that might be present in long alkyl chain groups in the precursor [19]. The relative band at $2494 \mathrm{~cm}^{-1}$ can be attributed to aliphatic $\mathrm{C}-\mathrm{H}$ stretching vibrations. The bands at 1731-1610 $\mathrm{cm}-1$ can be related to $\mathrm{C}-\mathrm{O}$ stretching from ketones, aldehydes, carboxylic or aromatic $\mathrm{C}-\mathrm{C}$ stretching vibrations. The 
broad and very intense bands at $1300-1000 \mathrm{~cm}^{-1}$ can be referred to as C-O bonds such as lactones, ethers and phenols [20].

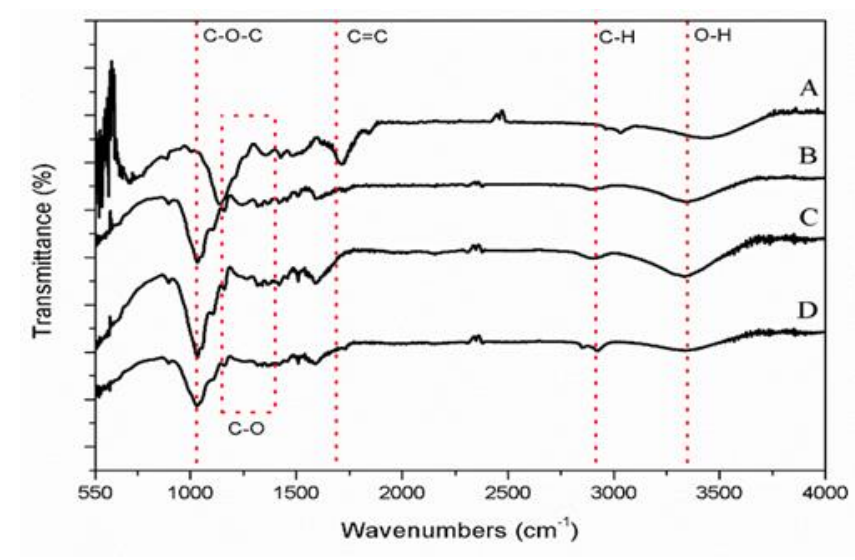

Figure 1. FTIR spectrum: (A) Husk, (B) HW, (C) HNa, (D) HK.

The bands at $1455 \mathrm{~cm}^{-1}$ and $1366 \mathrm{~cm}-1$ are deformation peaks from $\mathrm{CH}_{2}$ lignin and hemicelluloses; and deformation peaks from $\mathrm{C}-\mathrm{H}$ cellulose and hemicellulose, respectively. The peak intensity at $3334 \mathrm{~cm}^{-1}$ increased due to O-H hydrogen bond interactions in adsorbent produced with water $(\mathrm{HW})$ and it decreased with the use of $\mathrm{K}_{2} \mathrm{CO}_{3}$ and $\mathrm{Na}_{2} \mathrm{CO}_{3}$ in activation. The band densities in the spectrum range of 2922-2851 $\mathrm{cm}^{-1}$ (C-H bond region) altered considerably compared to the raw husk via activation. Weak intensities of many weak bonds in raw materials can be greatly reduced by microwave activation [19]. Moreover, the activation methods applied on adsorbents can significantly increase the number of $\mathrm{C}-\mathrm{C}$ bonds as well as the abundance of oxygen and hydrogen atoms [21].

FE-SEM images (Figure 2) also indicated that the morphology of the husk was altered by activation methods applied. Husk had a relatively denser and rougher surface compared to microwave activated adsorbents treated with either water, $\mathrm{Na}_{2} \mathrm{CO}_{3}$ or $\mathrm{K}_{2} \mathrm{CO}_{3}$. The microwave treated adsorbents had a more abundant number of pores on the surface. Those pores may be formed by evaporation of the activating agent from the surface of adsorbents and leaving the space behind, which was previously occupied by activating agents [19, 22-23]. HK had many micropores, and the micropores were observed to collapse in HNa.
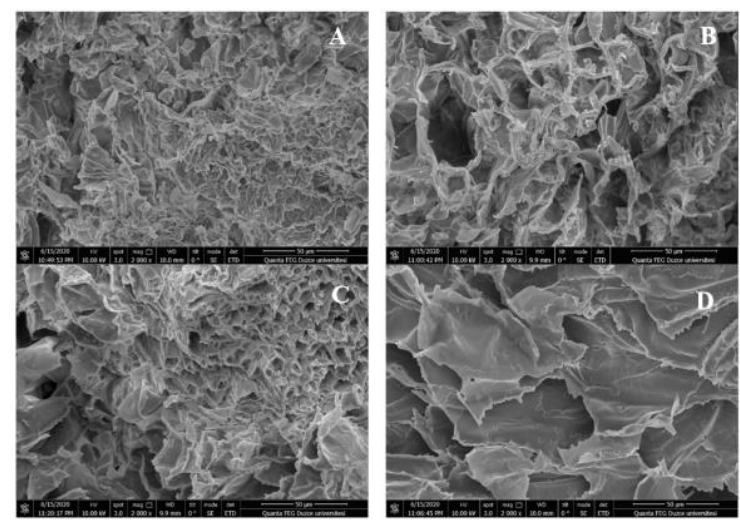

Figure 2. FE-SEM images: (A) Husk, (B) HW, (C) HNa, (D) HK. 


\subsection{Adsorption of $\mathrm{MB}$}

The total experimental period of adsorption (1080 min) ended with residual MB concentrations of 3.16, 4.14 and 3.37 $\mathrm{mg} / \mathrm{L}$, which were slightly above the measured concentration at $1020 \mathrm{~min}$ (Figure 3). This fact indicated that desorption of MB started between the operation periods of 1020 and 1080 min. Thus, further evaluation on the removal of MB and analysis for both kinetic and isotherm models was reported for the adsorption phase only, between operation periods of 0 and $1020 \mathrm{~min}$. Water and microwave treated sample, HW, was observed to be fast-responsive to the adsorption by $68 \% \mathrm{MB}$ removal compared to $\mathrm{HNa}(57 \%)$ and $\mathrm{HK}(55 \%)$ at the first $60 \mathrm{~min}$.

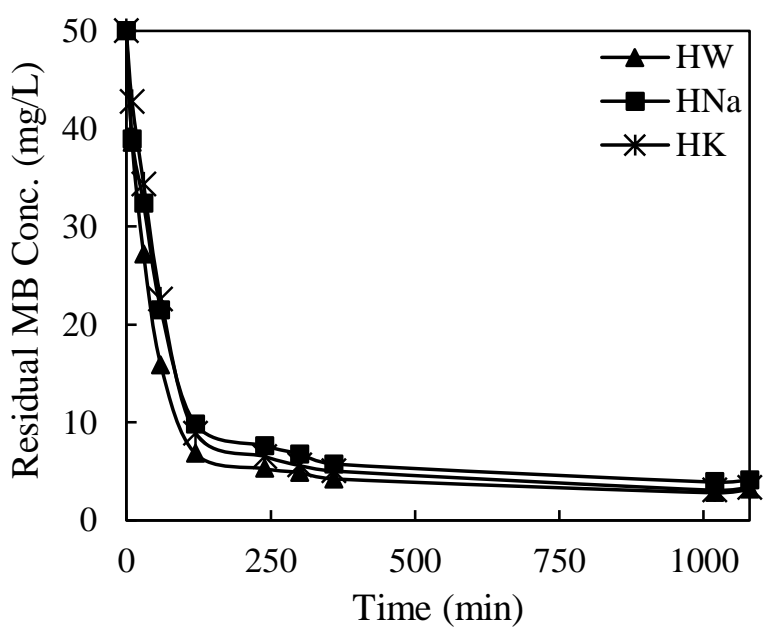

Figure 3. Retentate concentrations of MB during adsorption experiment (MB: $50 \mathrm{mg} / \mathrm{L}$, Adsorbent: $1 \mathrm{~g} / \mathrm{L}, \mathrm{pH} \sim 5.5,20-25^{\circ} \mathrm{C}$ ).

The removal of MB using $\mathrm{HW}, \mathrm{HNa}$ and $\mathrm{HK}$ as adsorbents was completed by $86 \%, 80 \%$ and $82 \%$, respectively, at the first $120 \mathrm{~min}$ of operation. MB removal was almost equilibrated at the end of the total operation period for the three adsorbents. Total MB removals obtained were $94 \%$ for $\mathrm{HW}, 92 \%$ for $\mathrm{HNa}$ and $94 \%$ for $\mathrm{HK}$ at $1020 \mathrm{~min}$. The corresponding experimental adsorption capacities at equilibrium ( $\mathrm{q}_{\mathrm{e}, \exp }$ ) were found as $47.18 \mathrm{mg} / \mathrm{g}$ for $\mathrm{HW}, 46.09 \mathrm{mg} / \mathrm{g}$ for $\mathrm{HNa}$ and $46.92 \mathrm{mg} / \mathrm{g}$ for HK. The adsorption capacity of HW $(47.18 \mathrm{mg} / \mathrm{g})$ was slightly higher than HNa (46.09 $\mathrm{mg} / \mathrm{g}$ ) and $\mathrm{HK}(46.92 \mathrm{mg} / \mathrm{g})$. Thus, microwave irradiation using deionized water as an activator, instead of any chemical, can also lead to comparable results. This fact may be due to the occupying of the active sites of the adsorbents by the chemicals used, namely $\mathrm{Na}^{+}$and $\mathrm{K}^{+}$ions, or the formation of the $\mathrm{MB}$ and salt complexes which may limit the adsorption of MB [24].

The adsorption capacities of produced adsorbents for MB removal were higher than or comparable to many adsorbents produced from agricultural wastes such as banana peel $(15.9 \mathrm{mg} / \mathrm{g})$, orange peel $(13.9 \mathrm{mg} / \mathrm{g})$ [9] and activated banana bark (40 mg/g), bagasse (38 mg/g) and pea shell charcoal (44 mg/g) reported for the removal of certain dyes [25]. The results were also compared with the studies aiming at the removal of MB (Table 2). The MB adsorption capacity of the adsorbents produced in this study was found to be comparable with those produced from the coffee husk, sugarcane bagasse, grape peel and Moroccan pozzolana at similar initial concentrations. The adsorption capacity obtained for pretreated coffee husk at an initial MB concentration of $50 \mathrm{mg} / \mathrm{L}$ was recorded as $49.40 \mathrm{mg} / \mathrm{g}$ [20]. To point out, the adsorption capacity obtained for the coffee husk was reached after multiple treatments of the husk, such as heating, drying, pyrolyzing under pure nitrogen and again heating. All these treatment steps are energy-intensive processes. The 
activation of the hazelnut husk was performed by microwave irradiation for only 7 minutes, in our study. Microwave irradiation has a short heating period, less energy and chemical consumption, and accurate temperature control [26]. Hazelnut husk can be valorized via the production of activated carbon (AC) (Table 2) and the AC can potentially yield better MB removals $[12,16]$. Even though AC has a unique adsorption capacity for the removal of pollutants [9], conventional thermal treatment of the husk for prolonged periods may hinder its economic advantage.

Table 2. Methylene blue adsorption capacity of various adsorbents.

\begin{tabular}{|c|c|c|c|c|}
\hline Raw waste & Treatment of raw waste & $\begin{array}{l}\text { Initial MB } \\
\text { concentration }\end{array}$ & $\begin{array}{l}\text { Adsorption } \\
\text { capacity }\end{array}$ & Reference \\
\hline \multirow{2}{*}{ Coffee husk } & \multirow{2}{*}{$\begin{array}{l}\text { Application of } 1 \mathrm{M} \mathrm{KOH} \text { to husk + heating at } 130{ }^{\circ} \mathrm{C} \text { for } 2 \mathrm{~h}+ \\
\text { drying at } 105{ }^{\circ} \mathrm{C} \text { for } 12 \mathrm{~h}+\text { pyrolyzing under pure nitrogen } \\
(95.995 \%) \text { for } 2 \mathrm{~h}+\text { heating at } 800{ }^{\circ} \mathrm{C}\end{array}$} & $50 \mathrm{mg} / \mathrm{L}$ & $49.4 \mathrm{mg} / \mathrm{g}$ & \multirow{2}{*}[20]{} \\
\hline & & $500 \mathrm{mg} / \mathrm{L}$ & $415.7 \mathrm{mg} / \mathrm{g}$ & \\
\hline \multirow{2}{*}{$\begin{array}{l}\text { Sugarcane } \\
\text { bagasse }\end{array}$} & \multirow{2}{*}{$\begin{array}{l}\text { Mixed with } \mathrm{Fe}\left(\mathrm{NO}_{3}{ }^{-}\right)_{3} \cdot 9 \mathrm{H}_{2} \mathrm{O}+\text { microwave application for } 750 \\
\text { W for } 75 \text { seconds }\end{array}$} & $100 \mathrm{mg} / \mathrm{L}$ & $18.4 \mathrm{mg} / \mathrm{g}$ & \multirow{2}{*}[26]{} \\
\hline & & $1000 \mathrm{mg} / \mathrm{L}$ & $36.0 \mathrm{mg} / \mathrm{g}$ & \\
\hline \multirow{2}{*}{ Grape peel } & \multirow{2}{*}{ Heated at $180{ }^{\circ} \mathrm{C}$ for $3 \mathrm{~min}$ in a microwave } & $100 \mathrm{mg} / \mathrm{L}$ & $38.4 \mathrm{mg} / \mathrm{g}$ & \multirow{2}{*}{ [27] } \\
\hline & & $600 \mathrm{mg} / \mathrm{L}$ & $207.6 \mathrm{mg} / \mathrm{g}$ & \\
\hline $\begin{array}{l}\text { Moroccan } \\
\text { pozzolana }\end{array}$ & None & & $43.9 \mathrm{mg} / \mathrm{g}$ & {$[28]$} \\
\hline Bean peel & \multirow{3}{*}{$\begin{array}{l}\text { Carbonization at varying temperatures between } 623-923 \mathrm{~K}+ \\
\mathrm{KOH}+\text { microwave at } 800 \mathrm{~W} \text { and } 7 \mathrm{~min}\end{array}$} & $10 \mathrm{mg} / \mathrm{L}$ & $19.6 \mathrm{mg} / \mathrm{g}$ & \multirow{3}{*}[29]{} \\
\hline Acorn peel & & $10 \mathrm{mg} / \mathrm{L}$ & $17.2 \mathrm{mg} / \mathrm{g}$ & \\
\hline $\begin{array}{l}\text { Pistacia } \\
\text { lentiscus }\end{array}$ & & $10 \mathrm{mg} / \mathrm{L}$ & $17.9 \mathrm{mg} / \mathrm{g}$ & \\
\hline \multirow{3}{*}{ Rice husk } & $\mathrm{NaOH}$ & & $39.2 \mathrm{mg} / \mathrm{g} *$ & \multirow{3}{*}[30]{} \\
\hline & Ultrasound & & $23.5 \mathrm{mg} / \mathrm{g} *$ & \\
\hline & supercritical $\mathrm{CO}_{2}$ & & $18.4 \mathrm{mg} / \mathrm{g} *$ & \\
\hline \multirow{2}{*}{$\begin{array}{l}\text { Hazelnut } \\
\text { husk }\end{array}$} & \multirow{2}{*}{$\mathrm{H}_{3} \mathrm{PO}_{4}+$ under nitrogen at $500{ }^{\circ} \mathrm{C}$ for $3 \mathrm{~h}(\mathrm{AC})$} & $50 \mathrm{mg} / \mathrm{L}$ & $50.0 \mathrm{mg} / \mathrm{g}$ & \multirow{2}{*}[12]{} \\
\hline & & $400 \mathrm{mg} / \mathrm{L}$ & $197.0 \mathrm{mg} / \mathrm{g}$ & \\
\hline \multirow{2}{*}{$\begin{array}{l}\text { Hazelnut } \\
\text { husk }\end{array}$} & \multirow{2}{*}{$\mathrm{ZnCl}_{2}+$ under nitrogen at $700{ }^{\circ} \mathrm{C}$ for $4 \mathrm{~h}\left(\mathrm{ZnCl}_{2}-\mathrm{AC}\right)$} & $100 \mathrm{mg} / \mathrm{L}$ & $194.9 \mathrm{mg} / \mathrm{g}$ & \multirow{2}{*}[16]{} \\
\hline & & $500 \mathrm{mg} / \mathrm{L}$ & $456.0 \mathrm{mg} / \mathrm{g}$ & \\
\hline $\begin{array}{l}\text { Hazelnut } \\
\text { husk }\end{array}$ & $\begin{array}{l}\text { deionized water application for a day + microwave at } 500 \mathrm{~W} \text {, } \\
60^{\circ} \mathrm{C}, 7 \mathrm{~min}\end{array}$ & $50 \mathrm{mg} / \mathrm{L}$ & $47.18 \mathrm{mg} / \mathrm{g}$ & This study \\
\hline $\begin{array}{l}\text { Hazelnut } \\
\text { husk }\end{array}$ & $\begin{array}{l}4 \mathrm{M} \mathrm{Na} \mathrm{CO}_{3} \text { application for a day + microwave at } 500 \mathrm{~W}, 60 \\
{ }^{\circ} \mathrm{C}, 7 \mathrm{~min}\end{array}$ & $50 \mathrm{mg} / \mathrm{L}$ & $46.09 \mathrm{mg} / \mathrm{g}$ & This study \\
\hline $\begin{array}{l}\text { Hazelnut } \\
\text { husk }\end{array}$ & $\begin{array}{l}4 \mathrm{M} \mathrm{K}_{2} \mathrm{CO}_{3} \text { application for a day }+ \text { microwave at } 500 \mathrm{~W}, 60 \\
{ }^{\circ} \mathrm{C}, 7 \mathrm{~min}\end{array}$ & $50 \mathrm{mg} / \mathrm{L}$ & $46.92 \mathrm{mg} / \mathrm{g}$ & This study \\
\hline
\end{tabular}

${ }^{*}$ Maximum adsorption capacity calculated according to the Langmuir isotherm at $25^{\circ} \mathrm{C}$.

The $\mathrm{pH}$ and temperature are the factors that affect the $\mathrm{MB}$ adsorption capacity of the adsorbent via altering the chemistry of the adsorbent and dye molecules. MB adsorption can be expected to decrease when the $\mathrm{pH}$ is low. The decrease in MB adsorption can be related to the protonation of MB in an acidic medium and the competing of the cations of dyes with excess hydrogen ions for active adsorption sites. Positively charged sites may decrease and negatively charged sites may increase, as the $\mathrm{pH}$ increases. The increase in negative charges on the adsorbent surface at high pHs creates an electrical double layer and changes the polarity of the adsorbent, which induces adsorption capacity [31]. The optimum $\mathrm{pH}$ of $\mathrm{MB}$ solution was previously recorded at 11.2-11.5 for microwave treated grape peel [27], 7 for $\mathrm{ZnCl}_{2}-\mathrm{AC}_{\text {of }}$ 
hazelnut husk [16] and below 5 for microwave treated bamboo charcoal [32]. Therefore, the general conclusion made on the improvement of MB adsorption in alkali environment can alter depending on the origin, and the treatment of the raw material. On the other hand, $\mathrm{MB}$ removal efficiencies in the $\mathrm{pH}$ range of 2 or 4 to 10 were regarded as insignificant $[26,33]$. Additionally, keeping the original $\mathrm{pH}$ of the solution prevents the consumption of the chemicals used in $\mathrm{pH}$ regulation. Thus, the rest of the studies was conducted at the $\mathrm{pH}$ of initial MB solution (i.e., 5.5).

The adsorption process can be either endothermic or exothermic. Temperature increase results in an increase in the adsorption capacity of pollutants in endothermic reactions and a decrease in exothermic reactions [34]. The MB adsorption on the heat-, chemical- or microwave-treated organic wastes has been mostly stated as an endothermic process $[12,16,26,31-35]$.

\section{Adsorption Kinetics}

Kinetic study on adsorption data provides beneficial information on reaction pathways and adsorption mechanisms [35]. The data on MB removal with HW, HNa and HK adsorbents were analysed by four different kinetic models (pseudofirst-order, pseudo-second-order, intraparticle diffusion and Elovich models). The related kinetic curves in linear form and the data on kinetic constants for each adsorbent material are presented in Figure 4 and Table 3, respectively.
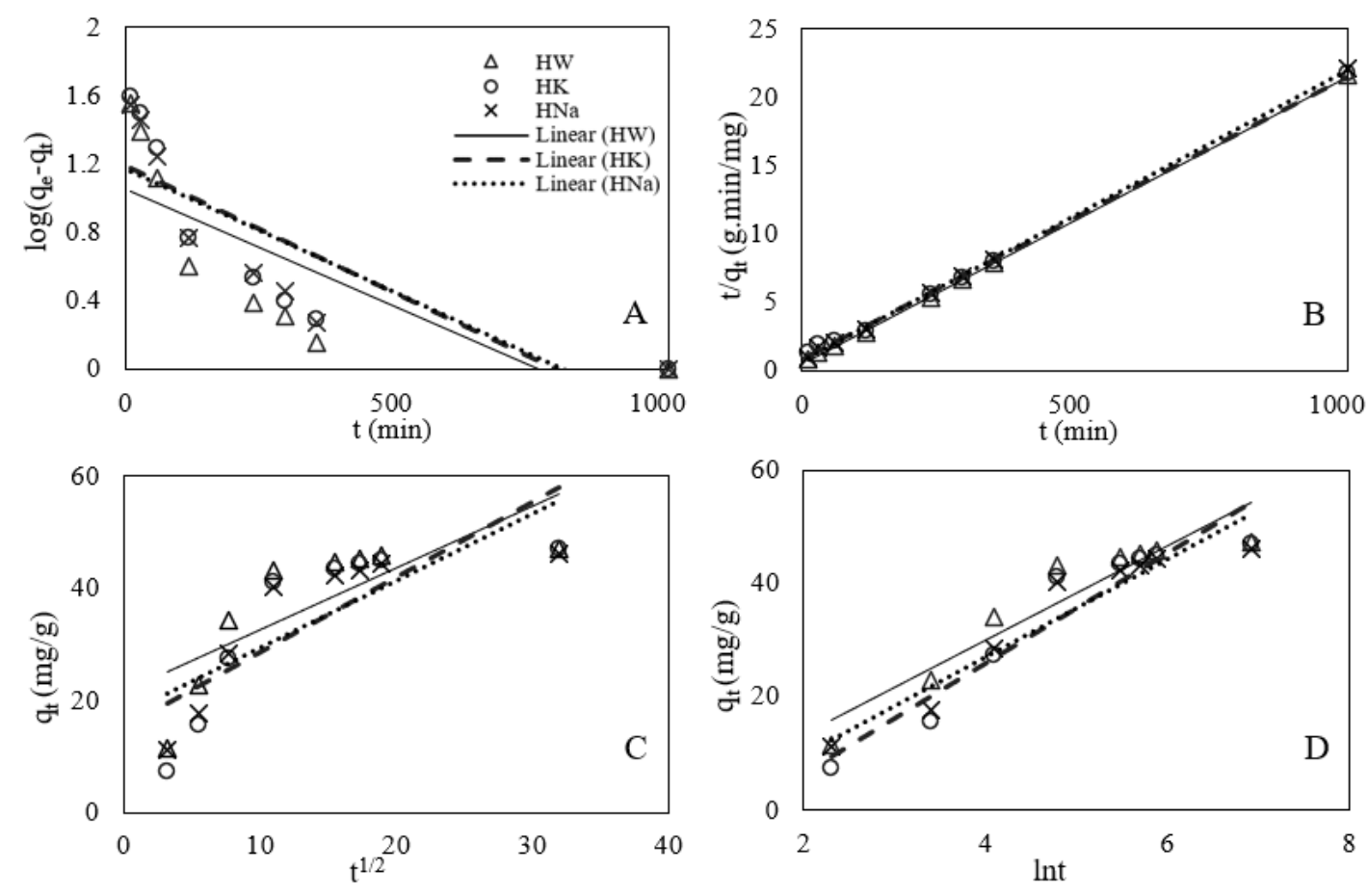

Figure 4. MB adsorption kinetics: (A) Pseudo first-order, (B) Pseudo second-order, (C) Intraparticle diffusion, (D) Elovich.

The coefficient of determination values $\left(\mathrm{R}^{2}\right)$ obtained from linearized kinetic expressions were in the range of 0.9981 0.9996 considering all adsorbents when the pseudo-second-order kinetic model was applied (Table 3 ). Since $\mathrm{R}^{2}$ values were very close to 1 , it can be concluded that the pseudo-second-order model can best represent the reaction mechanism of the adsorption process. This model assumes a proportionality between the occupation rate of adsorption sites and the square of the number of unoccupied sites [36]. Additionally, qe,exp values $(47.18,46.92$ and $46.09 \mathrm{mg} / \mathrm{g}$ for HW, HK and 
$\mathrm{HNa}$, respectively) were very close to the calculated adsorption capacity $\left(\mathrm{q}_{\mathrm{e}, \mathrm{cal}}\right)$ using pseudo-second-order kinetic model (48.54, 49.50 and $47.85 \mathrm{mg} / \mathrm{g}$ for HW, HK and HNa, respectively). This fact indicated that chemisorption was the main sorption mechanism led by the exchange and share of electrons between the adsorbent and adsorbate [35, 37]. Thus, the rate of the adsorption process was mainly controlled by chemical reactions between each element in the MB adsorption system which may be driven by the number of active sites for binding [38].

Moreover, the equilibrium rate constant for pseudo-second-order reaction $\left(\mathrm{k}_{2}\right)$ ranged between $4.59-8.25 \times 10^{-4}$. Such low values of $k_{2}$ were previously reported as being indicative of a rapid adsorption process [39]. The $\mathrm{R}^{2}$ of the linearized Elovich model was between 0.8852 and 0.9145 and was also higher than pseudo-first-order and intraparticle diffusion kinetic models (in the range of 0.5811-0.6858). The applicability of both pseudo-second-order and Elovich models is strong evidence for chemisorption of MB dye on HW, HNa and HK [40]. Pseudo-first-order and intraparticle diffusion kinetic models were found not to be applicable for the MB adsorption process on the produced adsorbents due to relatively much lower $\mathrm{R}^{2}$ values (0.5811-0.6858 and 0.6056-0.6734, respectively).

Table 3. Kinetic models and calculated parameters

\begin{tabular}{|c|c|c|c|c|c|c|}
\hline Kinetic model & Linear equation & Parameters & HW & HNa & HK & Reference \\
\hline \multirow{3}{*}{ Pseudo first-order ${ }^{\mathrm{a}}$} & \multirow{3}{*}{$\begin{array}{l}\log \left(q_{e}-q_{t}\right)=\log q_{e}- \\
\frac{\mathrm{k}_{1}}{2.303} t\end{array}$} & $\mathrm{q}_{\mathrm{e}, \mathrm{cal}}(\mathrm{mg} / \mathrm{g})$ & 11.26 & 14.84 & 15.51 & \multirow[t]{3}{*}[41]{} \\
\hline & & $\mathrm{k}_{1}(1 / \mathrm{min})$ & $3.22 \times 10^{-3}$ & $3.22 \times 10^{-3}$ & $3.45 \times 10^{-3}$ & \\
\hline & & $\mathrm{R}^{2}$ & 0.5811 & 0.6858 & 0.6622 & \\
\hline \multirow{2}{*}{$\begin{array}{l}\text { Pseudo second- } \\
\text { order }^{\text {b }}\end{array}$} & \multirow{2}{*}{$\frac{t}{q_{t}}=\frac{1}{k_{2} q_{e}^{2}}+\frac{t}{q_{e}}$} & $\mathrm{q}_{\mathrm{e}, \mathrm{cal}}(\mathrm{mg} / \mathrm{g})$ & $\begin{array}{l}48.54 \\
825 \times 10^{-4}\end{array}$ & $\begin{array}{l}47.85 \\
504 \times 10^{-4}\end{array}$ & 49.50 & \multirow[t]{2}{*}{ [41] } \\
\hline & & $\mathrm{R}^{2}$ & 0.9996 & 0.9993 & 0.9981 & \\
\hline \multirow{3}{*}{$\begin{array}{l}\text { Intraparticle } \\
\text { diffusion }^{\mathrm{c}}\end{array}$} & \multirow{3}{*}{$\mathrm{q}_{\mathrm{t}}=\mathrm{k}_{\mathrm{p}} \mathrm{t}^{\frac{1}{2}}+\mathrm{C}$} & $\mathrm{k}_{\mathrm{p}}$ & 1.11 & 1.19 & 1.34 & \multirow{3}{*}{ [35] } \\
\hline & & $\mathrm{C}$ & 21.43 & 17.56 & 15.29 & \\
\hline & & $\mathrm{R}^{2}$ & 0.6056 & 0.6734 & 0.6575 & \\
\hline \multirow{3}{*}{ Elovich $^{\mathrm{d}}$} & \multirow{3}{*}{$\mathrm{q}_{\mathrm{t}}=\frac{1}{\beta}(\alpha \beta)+\frac{1}{\beta} \ln \mathrm{t}$} & $\beta(\mathrm{g} / \mathrm{mg})$ & 0.12 & 0.11 & 0.10 & \multirow{3}{*}{ [35] } \\
\hline & & $\alpha(\mathrm{mg} / \mathrm{g} \min )$ & 3.09 & 7.77 & 13.36 & \\
\hline & & $\mathrm{R}^{2}$ & 0.8852 & 0.9145 & 0.9073 & \\
\hline
\end{tabular}

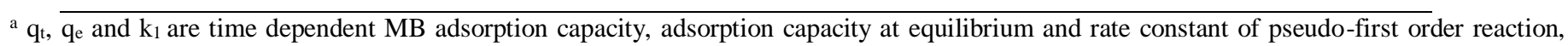
respectively.

${ }^{\mathrm{b}} \mathrm{k}_{2}$ is the equilibrium rate constant for pseudo second-order reaction.

${ }^{\mathrm{c}} \mathrm{k}_{\mathrm{p}}$ and $\mathrm{C}$ are intraparticle diffusion and the diffusion constants, respectively.

${ }^{\mathrm{d}} \alpha$ indicates the primary adsorption extent and $\beta$ indicates the adsorbent area occupied by adsorbates.

\subsection{Adsorption Isotherms}

Isotherm models are used to predict the affinity of adsorbate (i.e., MB dye) to the adsorbent. A correlation between the total amount of adsorbate and the retaining amount of adsorbate in solution under equilibrium conditions is being established with isotherm applications [42]. In this study, four different isotherm models were analysed for MB removal by $\mathrm{HW}, \mathrm{HNa}$ and $\mathrm{HK}$ adsorbents. The related isotherm curves in linear form and the data on isotherm constants for each adsorbent are presented in Figure 5 and Table 4, respectively. The $\mathrm{R}^{2}$ values obtained were between 0.8165-0.8946 for 
all adsorbents according to Langmuir isotherm which was higher than those of Freundlich isotherm (0.8107-0.8598). The separation factor in Langmuir $\left(\mathrm{R}_{\mathrm{L}}\right)$ indicates whether adsorption is favourable $\left(0<\mathrm{R}_{\mathrm{L}}<1\right)$, unfavourable $\left(\mathrm{R}_{\mathrm{L}}>1\right)$, linear $\left(R_{L}=1\right)$, or irreversible $\left(R_{L}=0\right)$. This factor was calculated as 0.09 for HW, 0.10 for HNa and 0.11 for HK, which were between 0 and 1. Thus, MB dye adsorption on adsorbents was found to be favourable [43-44]. The best-fitted isotherm model was Temkin isotherm with $\mathrm{R}^{2}$ of $0.9220,0.9413$ and 0.9300 for HW, HNa and HK, respectively. Temkin isotherm assumes that the binding energies in the adsorption process are uniformly distributed. The surface coverage owing to the interactions between adsorbent and adsorbate results in a decrease in the heat of adsorption of all molecules [28]. The enthalpy of the adsorbate has a linear correlation with interactions. The factors affecting adsorption are considered as density and distribution of the active sites of both adsorbent and adsorbate in Temkin isotherm [5]. Furthermore, Temkin isotherm constant, $b_{t}$, ranged between $0.158-0.182 \mathrm{kj} / \mathrm{mol}$ considering all adsorbents produced (Table 4). Adsorption energy was previously reported to be less than $8 \mathrm{~kJ} / \mathrm{mol}$ [45-46] for a typical physisorption process, and in the range of $8-16 \mathrm{~kJ} / \mathrm{mol}$ for an ion-exchange process [47] according to Temkin isotherm. However, the $b_{t}$ values calculated were not close to the previously defined levels, representing a complex adsorption process and may involve both chemisorption and physisorption [5, 48]. Harkins-Jura isotherm was not applicable for the MB adsorption process on $\mathrm{HW}, \mathrm{HNa}$ and $\mathrm{HK}$ based on relatively much lower $\mathrm{R}^{2}$ values obtained (0.4835-0.6128).
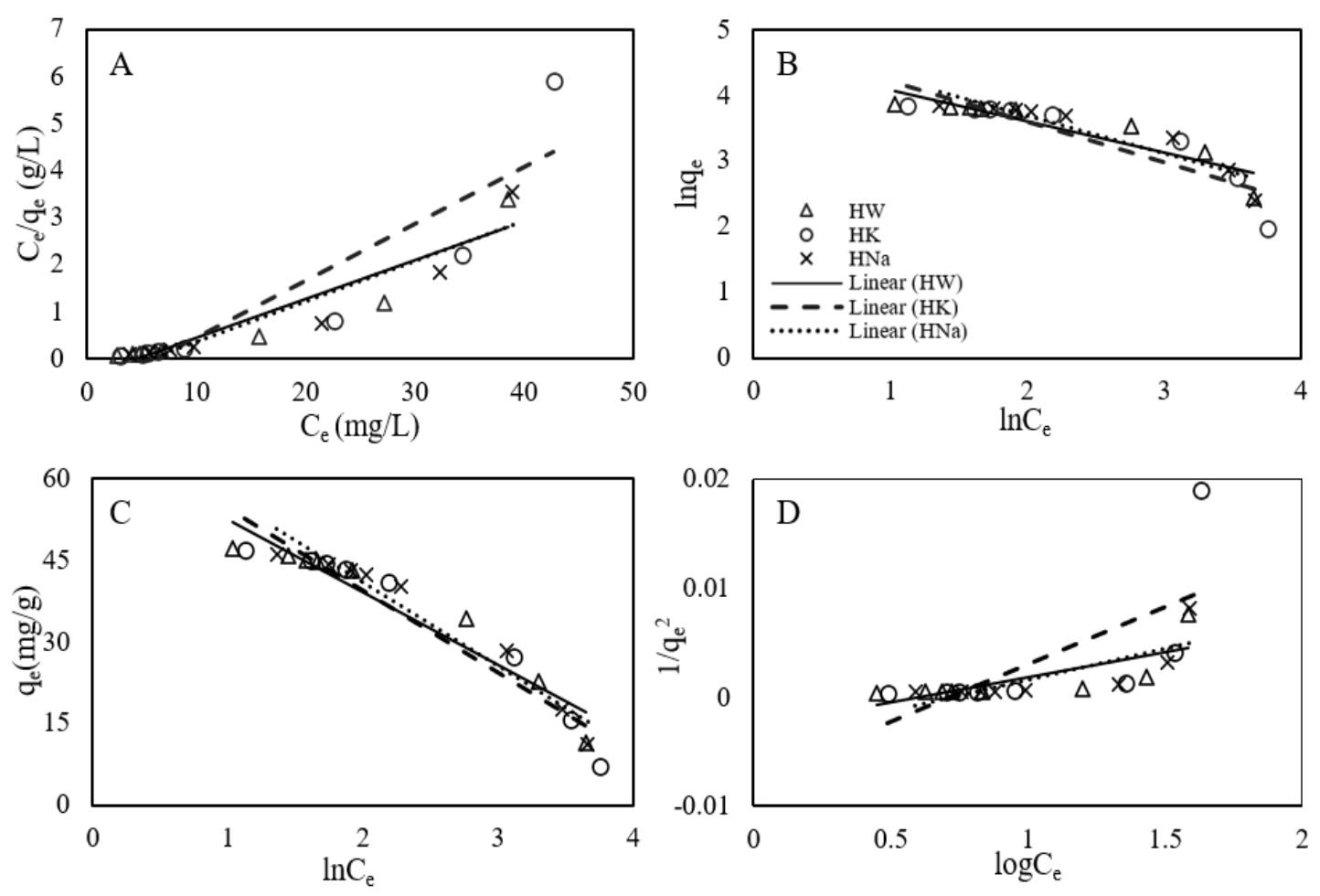

Figure 5. MB adsorption isotherms: (A) Langmuir, (B) Freundlich, (C) Temkin, (D) Harkins-Jura 
Table 4. Isotherm models and calculated parameters

\begin{tabular}{|c|c|c|c|c|c|c|}
\hline Isotherm & Linear equation & Parameters & HW & HNa & HK & Reference \\
\hline \multirow[t]{4}{*}{ Langmuir $^{a}$} & \multirow{4}{*}{$\begin{array}{l}\frac{C_{e}}{q_{e}}=\frac{1}{K_{L} q_{m}}+\frac{C_{e}}{q_{m}} \\
R_{L}=\frac{1}{1+K_{L} C_{0}}\end{array}$} & $q_{m}(m g / g)$ & 12.13 & 11.59 & 8.33 & \multirow[t]{4}{*}[43,49]{} \\
\hline & & $K_{L}(L / m g)$ & 0.21 & 0.17 & 0.16 & \\
\hline & & $R_{L}$ & 0.09 & 0.10 & 0.11 & \\
\hline & & $R^{2}$ & 0.8846 & 0.8946 & 0.8165 & \\
\hline \multirow[t]{3}{*}{ Freundlich $^{\text {b }}$} & \multirow{3}{*}{$\ln q_{e}=\ln K_{f}+\frac{1}{n} C_{e}$} & $K_{F}(m g / g)$ & 95.40 & 126.06 & 127.59 & \multirow[t]{3}{*}[50]{} \\
\hline & & $1 / n$ & 0.48 & 0.57 & 0.62 & \\
\hline & & $R^{2}$ & 0.8221 & 0.8598 & 0.8107 & \\
\hline \multirow[t]{3}{*}{ Temkin $^{c}$} & \multirow{3}{*}{$q_{e}=\frac{R T}{b_{T}} \ln C_{e+} \frac{R T}{b_{T}} \ln A$} & $A$ & 139.77 & 105.64 & 100.58 & \multirow[t]{3}{*}{ [28] } \\
\hline & & $b_{t}(\mathrm{~kJ} / \mathrm{mol})$ & 0.182 & 0.158 & 0.161 & \\
\hline & & $R^{2}$ & 0.9220 & 0.9413 & 0.9300 & \\
\hline \multirow[t]{3}{*}{ Harkins-Jura $^{d}$} & \multirow{3}{*}{$\frac{1}{q_{e}^{2}}=\frac{B_{H}}{A_{H}}-\frac{1}{A_{H}} \log C_{e}$} & $B_{H}$ & 0.59 & 0.74 & 1.00 & \multirow[t]{3}{*}{ [51] } \\
\hline & & $A_{H}$ & 217.39 & 175.44 & 94.34 & \\
\hline & & $R^{2}$ & 0.5690 & 0.6128 & 0.4835 & \\
\hline
\end{tabular}

${ }^{a} \mathrm{q}_{\mathrm{m}}$ is maximum adsorption capacity, $\mathrm{C}_{\mathrm{e}}$ is equilibrium concentration of $\mathrm{MB}, \mathrm{q}_{\mathrm{e}}$ is amount of $\mathrm{MB}$ absorbed at equilibrium, $\mathrm{K}_{\mathrm{L}}$ is Langmuir isotherm constant. $\mathrm{R}_{\mathrm{L}}$ is the separation factor and $\mathrm{C}_{\mathrm{o}}$ is the initial $\mathrm{MB}$ concentration.

${ }^{\mathrm{b}} \mathrm{K}_{\mathrm{F}}$ is Freundlich constant, $\mathrm{n}$ is a constant indicating adsorption intensity.

${ }^{c} \mathrm{R}, \mathrm{T}, \mathrm{A}$ and $\mathrm{b}_{\mathrm{t}}$ are gas constant, absolute temperature, Temkin isotherm equilibrium binding constant and Temkin isotherm constant, respectively.

${ }^{\mathrm{d}} \mathrm{B}_{\mathrm{H}}$ and $\mathrm{AH}_{\mathrm{H}}$ are isotherm constants of Harkins-Jura model.

\section{Conclusion}

This study was conducted for the purpose of investigating the potential of hazelnut husk as an adsorbent material after being pre-treated with chemical/water and microwave applications. All adsorbent materials produced were structurally altered after pre-treatments applied either by chemical/water or microwave exposure. The MB removal was attained in the range of $92-94 \%$ resulting in an adsorption capacity of the produced adsorbents in the range of 46.09-47.18 mg/g. The isotherm and kinetic models tested revealed that the adsorption process was favourable, and chemical interactions predominantly controlled the sorption. Adsorbent materials produced showed a promising adsorption capacity for dye removal. However, process parameters are required to be further optimized to be able to valorize the husk as an adsorbent.

\section{Acknowledgements}

This study is supported by Duzce University Scientific Research Projects Coordination Unit. Project Number: DUBAP2020.06.02.1072.

\section{References}

[1] M. N. Rashed, Adsorption Technique for the Removal of Organic Pollutants from Water and Wastewater. In M.N. Rashed,ed., Org. Pollut. - Monit. Risk Treat. (IntechOpen, 2013). https://doi.org/10.5772/54048.

[2] E. Burakov, E. V. Galunin, I. V. Burakova, A. E. Kucherova, S. Agarwal, A. G. Tkachev, V. K. Gupta, Adsorption of heavy metals on conventional and nanostructured materials for wastewater treatment purposes: A review. Ecotoxicology and Environmental Safety, 148 (2018) 702-712. https://doi.org/10.1016/j.ecoenv.2017.11.034. 
[3] N. A. Fathy, O. I. El-shafey, L. B. Khalil, Effectiveness of alkali-acid treatment in enhancement the adsorption capacity for rice straw: The removal of methylene blue dye. ISRN Physical Chemistry, (2013). https://doi.org/10.1155/2013/208087.

[4] A. Najafpoor, O. Nemati Sani, H. Alidadi, M. Yazdani, A. A. Navaei Fezabady, M. Taghavi, Optimization of ciprofloxacin adsorption from synthetic wastewaters using $\gamma-\mathrm{Al}_{2} \mathrm{O}_{3}$ nanoparticles: An experimental design based on response surface methodology. Colloids and Interface Science Communications, 33 (2019) 100212. https://doi.org/10.1016/j.colcom.2019.100212.

[5] S. Sabar, H. A. Aziz, N. H. Yusof, S. Subramaniam, K. Y. Foo, L. D. Wilson, H. K. Lee, Preparation of sulfonated chitosan for enhanced adsorption of methylene blue from aqueous solution. Reactive and Functional Polymers, (2020) 104584. https://doi.org/10.1016/j.reactfunctpolym.2020.104584.

[6] K. Prajapati, M. K. Mondal, Comprehensive kinetic and mass transfer modeling for methylene blue dye adsorption onto $\mathrm{CuO}$ nanoparticles loaded on nanoporous activated carbon prepared from waste coconut shell. Journal of Molecular Liquids, 307 (2020) 112949. https://doi.org/10.1016/j.molliq.2020.112949.

[7] T. Kekes, C. Tzia, Adsorption of indigo carmine on functional chitosan and $\beta$-cyclodextrin/chitosan beads: Equilibrium, kinetics and mechanism studies. Journal of Environmental Management, 262 (2020) 110372. https://doi.org/10.1016/j.jenvman.2020.110372.

[8] S. De Gisi, G. Lofrano, M. Grassi, M. Notarnicola, Characteristics and adsorption capacities of low-cost sorbents for wastewater treatment: A review. Sustainable Materials and Technologies, 9 (2016) 10-40. https://doi.org/10.1016/j.susmat.2016.06.002.

[9] A. Bhatnagar, M. Sillanpää, Utilization of agro-industrial and municipal waste materials as potential adsorbents for water treatment-A review. Chemical Engineering Journal, 157 (2010) 277-296. https://doi.org/10.1016/j.cej.2010.01.007.

[10] TB (T. C. Ticaret Bakanlığ1), 2018 Y11ı Fındık Raporu (2019).

[11] İ. Doğan, M. Tekinok, Fındık zürufu ve deniz yosunlarından saksı toprağı geliştirilmesi. Sakarya Ticaret Borsas1, 41 (2011) 25-27.

[12] C. Ozer, M. Imamoglu, Y. Turhan, F. Boysan, Removal of methylene blue from aqueous solutions using phosphoric acid activated carbon produced from hazelnut husks. Toxicological and Environmental Chemistry, 94 (2012) 1283-1293. https://doi.org/10.1080/02772248.2012.707656.

[13] P. Liu, Z. Wu, X. Ge, X. Yang, Hydrothermal synthesis and microwave-assisted activation of starch-derived carbons as an effective adsorbent for naphthalene removal. RSC Advances Open, 9 (2019) 11696-11706. https://doi.org/10.1039/c9ra01386e.

[14] M. Imamoglu, Adsorption of Cd(II) ions onto activated carbon prepared from hazelnut husks. Journal of $\begin{array}{llllll}\text { Dispersion Science } 34 \text { and } & \text { (2013) }\end{array}$ https://doi.org/10.1080/01932691.2012.739869.

[15] M. Imamoglu, A. Ozturk, Ş. Aydın, A. Manzak, A. Gündoğdu, C. Duran, Adsorption of Cu(II) ions from aqueous solution by hazelnut husk activated carbon prepared with potassium acetate. Journal of Dispersion Science and Technology, 39 (2018) 1144-1148. https://doi.org/10.1080/01932691.2017.1385479.

[16] G. Karaçetin, S. Sivrikaya, M. Imamołlu, Adsorption of methylene blue from aqueous solutions by activated carbon prepared from hazelnut husk using zinc chloride. Journal of Analytical and Applied Pyrolysis, 110 (2014) 270-276. https://doi.org/10.1016/j.jaap.2014.09.006.

[17] S. Sivrikaya, S. Albayrak, M. Imamoglu, A. Gundogdu, C. Duran, H. Yildiz, Dehydrated hazelnut husk carbon: A novel sorbent for removal of $\mathrm{Ni}(\mathrm{II})$ ions from aqueous solution. Desalination and Water Treatment, 50 (2012) 2-13. https://doi.org/10.1080/19443994.2012.708234. 
[18] M. Imamoglu, H. Şahin, Ş. Aydın, F. Tosunoğlu, H. Yılmaz, S. Z. Yıldız, Investigation of Pb(II) adsorption on a novel activated carbon prepared from hazelnut husk by $\mathrm{K}_{2} \mathrm{CO}_{3}$ activation. Desalination and Water Treatment, 57 (2016) 4587-4596. https://doi.org/10.1080/19443994.2014.995135.

[19] H. Deng, G. Li, H. Yang, J. Tang, J. Tang, Preparation of activated carbons from cotton stalk by microwave assisted $\mathrm{KOH}$ and $\mathrm{K}_{2} \mathrm{CO}_{3}$ activation. Chemical Engineering Journal, 163 (2010) 373-381. https://doi.org/10.1016/j.cej.2010.08.019.

[20] T. H. Tran, A. H. Le, T. H. Pham, D. T. Nguyen, S. W. Chang, W. J. Chung, D. D. Nguyen, Adsorption isotherms and kinetic modeling of methylene blue dye onto a carbonaceous hydrochar adsorbent derived from coffee husk waste. Science of the Total Environment, 725 (2020) 138325. https://doi.org/10.1016/j.scitotenv.2020.138325.

[21] Y. Chen, Y. Zhu, Z. Wang, Y. Li, L. Wang, L. Ding, X. Gao, Y. Ma, Y. Guo, Application studies of activated carbon derived from rice husks produced by chemical-thermal process - A review. Advances in Colloid and Interface Science, 163 (2011) 39-52. https://doi.org/10.1016/j.cis.2011.01.006.

[22] Ahmadpour D. D. Do, The preparation of activated carbon from macadamia nutshell by chemical activation. Carbon, 35 (1997) 1723-1732.

[23] D. Prahas, Y. Kartika, N. Indraswati, S. Ismadji, Activated carbon from jackfruit peel waste by $\mathrm{H}_{3} \mathrm{PO}_{4}$ chemical activation: Pore structure and surface chemistry characterization. Chemical Engineering Journal, 140 (2008) 32-42. https://doi.org/10.1016/j.cej.2007.08.032.

[24] S. Al-Asheh, F. Banat, L. Abu-Aitah, The removal of methylene blue dye from aqueous solutions using activated and non-activated bentonites. Adsorption Science and Technology, 21 (2003) 451-462. https://doi.org/10.1260/026361703769645780.

[25] O. S. Bello, K. A. Adegoke, A. A. Olaniyan, H. Abdulazeez, Dye adsorption using biomass wastes and natural adsorbents: Overview and future prospects. Desalination and Water Treatment, 53 (2015) 12921315. https://doi.org/10.1080/19443994.2013.862028.

[26] W. Jiang, L. Zhang, X. Guo, M. Yang, Y. Lu, Y. Wang, Y. Zheng, G. Wei, Adsorption of cationic dye from water using an iron oxide/activated carbon magnetic composites prepared from sugarcane bagasse by microwave method. Environmental Technology (United Kingdom), (2019) 1-14. https://doi.org/10.1080/09593330.2019.1627425.

[27] L. Ma, C. Jiang, Z. Lin, Z. Zou, Microwave-hydrothermal treated grape peel as an efficient biosorbent for methylene blue removal. International Journal of Environmental Research and Public Health, 15 (2018). https://doi.org/10.3390/ijerph15020239.

[28] F. E. Titchou, R. A. Akbour, A. Assabbane, M. Hamdani, Removal of cationic dye from aqueous solution using Moroccan pozzolana as adsorbent: Isotherms, kinetic studies, and application on real textile wastewater treatment. Groundwater for Sustainable Development, 11 (2020) 100405. https://doi.org/10.1016/j.gsd.2020.100405.

[29] Kahoul, N. Bougdah, F. Djazi, C. Djilani, P. Magri, M. S. Medjram, Removal of methylene blue by adsorption onto activated carbons produced from agricultural wastes by microwave induced $\mathrm{KOH}$ activation. Chemistry and Chemical Technology, 13 (2019) 365-371. https://doi.org/10.23939/chcht13.03.365.

[30] D. S. P. Franco, E. H. Tanabe, D. A. Bertuol, G. S. Dos Reis, É. C. Lima, G. L. Dotto, Alternative treatments to improve the potential of rice husk as adsorbent for methylene blue. Water Science and Technology, 75 (2017) 296-305. https://doi.org/10.2166/wst.2016.504. 
O. O. Namal, E. Kalipci, Adsorption kinetics of methylene blue using alkali and microwave-modified apricot stones. Separation Science and Technology (Philadelphia), 54 (2019) 1722-1738. https://doi.org/10.1080/01496395.2018.1541469.

[32] P. Liao, Z. Malik Ismael, W. Zhang, S. Yuan, M. Tong, K. Wang, J. Bao, Adsorption of dyes from aqueous solutions by microwave modified bamboo charcoal. Chemical Engineering Journal, 195-196 (2012) 339346. https://doi.org/10.1016/j.cej.2012.04.092.

[33] O. Quansah, T. Hlaing, F. N. Lyonga, P. P. Kyi, S. H. Hong, C. G. Lee, S. J. Park, Nascent rice husk as an adsorbent for removing cationic dyes from textile wastewater. Applied Sciences (S witzerland), 10 (2020). https://doi.org/10.3390/app10103437.

M. A. Al-Ghouti, R. S. Al-Absi, Mechanistic understanding of the adsorption and thermodynamic aspects of cationic methylene blue dye onto cellulosic olive stones biomass from wastewater. Scientific Reports, 10 (2020) 1-18. https://doi.org/10.1038/s41598-020-72996-3.

[35] Sheikhmohammadi, M. Safari, A. Alinejad, A. Esrafili, H. Nourmoradi, E. Asgari, The synthesis and application of the $\mathrm{Fe}_{3} \mathrm{O}_{4} @ \mathrm{SiO}_{2}$ nanoparticles functionalized with 3-aminopropyltriethoxysilane as an efficient sorbent for the adsorption of ethylparaben from wastewater: Synthesis, kinetic, thermodynamic and equilibrium studies. Journal of Environmental Chemical Engineering, 7 (2019). https://doi.org/10.1016/j.jece.2019.103315.

[36] Mehdinia, S. Heydari, A. Jabbari, Synthesis and characterization of reduced graphene oxide$\mathrm{Fe}_{3} \mathrm{O}_{4} @$ polydopamine and application for adsorption of lead ions: Isotherm and kinetic studies. Materials Chemistry and Physics, 239 (2020) 121964. https://doi.org/10.1016/j.matchemphys.2019.121964.

N. Wekoye, W. C. Wanyonyi, P. T. Wangila, M. K. Tonui, Kinetic and equilibrium studies of Congo red dye adsorption on cabbage waste powder. Environmental Chemistry and Ecotoxicology, 2 (2020) 24-31. https://doi.org/10.1016/j.enceco.2020.01.004.

[38] P. B. Vilela, C. A. Matias, A. Dalalibera, V. A. Becegato, A. T. Paulino, Polyacrylic acid-based and chitosan-based hydrogels for adsorption of cadmium: Equilibrium isotherm, kinetic and thermodynamic studies. Journal of Environmental Chemical Engineering, 7 (2019) 103327. https://doi.org/10.1016/j.jece.2019.103327.

[39] Y. Dehmani, L. Sellaoui, Y. Alghamdi, J. Lainé, M. Badawi, A. Amhoud, A. Bonilla-Petriciolet, T. Lamhasni, S. Abouarnadasse, Kinetic, thermodynamic and mechanism study of the adsorption of phenol on Moroccan clay. Journal of Molecular Liquids, $312 \quad$ (2020) 113383. https://doi.org/10.1016/j.molliq.2020.113383.

[40] H. N. Bhatti, Y. Safa, S. M. Yakout, O. H. Shair, M. Iqbal, A. Nazir, Efficient removal of dyes using carboxymethyl cellulose/alginate/polyvinyl alcohol/rice husk composite: Adsorption/desorption, kinetics and recycling studies. International Journal of Biological Macromolecules, 150 (2020) 861-870. https://doi.org/10.1016/j.ijbiomac.2020.02.093.

[41] A. Akinpelu, M. E. Ali, M. R. Johan, R. Saidur, Z. Z. Chowdhury, A. M. Shemsi, T. A. Saleh, Effect of the oxidation process on the molecular interaction of polyaromatic hydrocarbons (PAH) with carbon nanotubes: Adsorption kinetic and isotherm study. Journal of Molecular Liquids, 289 (2019). https://doi.org/10.1016/j.molliq.2019.111107.

[42] S. Noreen, U. Khalid, S. M. Ibrahim, T. Javed, A. Ghani, S. Naz, M. Iqbal, ZnO, MgO and FeO adsorption efficiencies for direct sky-Blue dye: Equilibrium, kinetics and thermodynamics studies. Journal of Materials Research and Technology, 9 (2020) 5881-5893. https://doi.org/10.1016/j.jmrt.2020.03.115.

[43] M. Oloo, J. M. Onyari, W. C. Wanyonyi, J. N. Wabomba, V. M. Muinde, Adsorptive removal of hazardous crystal violet dye form aqueous solution using Rhizophora mucronata stem-barks: Equilibrium and kinetics 
studies. Environmental Chemistry and Ecotoxicology, 2 (2020) 64-72. https://doi.org/10.1016/j.enceco.2020.05.001.

[44] S. Anantha, S. Olivera, C. Hu, B. K. Jayanna, N. Reddy, K. Venkatesh, H. B. Muralidhara, R. Naidu, Comparison of the photocatalytic, adsorption and electrochemical methods for the removal of cationic dyes from aqueous solutions. Environmental Technology and Innovation, 17 (2020) 100612. https://doi.org/10.1016/j.eti.2020.100612.

[45] S. T. Araújo, I. L. S. Almeida, H. C. Rezende, S. M. L. O. Marcionilio, J. J. L. Léon, T. N. de Matos, Elucidation of mechanism involved in adsorption of $\mathrm{Pb}$ (II) onto lobeira fruit (Solanum lycocarpum) using Langmuir, Freundlich and Temkin isotherms. Microchemical Journal, 137 (2018) 348-354. https://doi.org/10.1016/j.microc.2017.11.009.

[46] S. Parvizi Ghaleh, E. Khodapanah, S. A. Tabatabaei-Nezhad, Comprehensive monolayer two-parameter isotherm and kinetic studies of thiamine adsorption on clay minerals: Experimental and modeling $\begin{array}{lllllll}\text { approaches. Journal of } & \text { Molecular } & \text { Liquids, } & 306 & \text { (2020) }\end{array}$ https://doi.org/10.1016/j.molliq.2020.112942.

[47] Y. Liu, Y. Xiong, P. Xu, Y. Pang, C. Du, Enhancement of Pb (II) adsorption by boron doped ordered mesoporous carbon: Isotherm and kinetics modeling. Science of the Total Environment, 708 (2020) 134918. https://doi.org/10.1016/j.scitotenv.2019.134918.

[48] X. J. Hu, J. S. Wang, Y. G. Liu, X. Li, G. M. Zeng, Z. L. Bao, X. X. Zeng, A. W. Chen, F. Long, Adsorption of chromium (VI) by ethylenediamine-modified cross-linked magnetic chitosan resin: Isotherms, kinetics and thermodynamics. Journal of Hazardous Materials, 185 (2011) 306-314. https://doi.org/10.1016/j.jhazmat.2010.09.034.

[49] J. Mate, S. Mishra, Synthesis of borax cross-linked Jhingan gum hydrogel for remediation of Remazol Brilliant Blue R (RBBR) dye from water: Adsorption isotherm, kinetic, thermodynamic and biodegradation studies. International Journal of Biological Macromolecules, 151 (2020) 677-690. https://doi.org/10.1016/j.ijbiomac.2020.02.192.

[50] H. Jawad, A. S. Abdulhameed, Mesoporous Iraqi red kaolin clay as an efficient adsorbent for methylene blue dye: Adsorption kinetic, isotherm and mechanism study. Surfaces and Interfaces, 18 (2020) 100422. https://doi.org/10.1016/j.surfin.2019.100422.

[51] V. Yönten, N. K. Sanyürek, M. R. Kivanç, A thermodynamic and kinetic approach to adsorption of methyl orange from aqueous solution using a low cost activated carbon prepared from Vitis vinifera L. Surfaces and Interfaces, 20 (2020) 1-8. https://doi.org/10.1016/j.surfin.2020.100529. 